\title{
Determinants of Employee Turnover In Public Universities In Nyeri County
}

\author{
Emily Karimi Saverio \\ Dedan Kimathi University Of Technology (Nyeri, Kenya) \\ Fr. Prof. Donatus Mathenge Githui \\ Dedan Kimathi University Of Technology (Nyeri, Kenya) \\ Dr. Susan Ngure \\ Dedan Kimathi University Of Technology (Nyeri, Kenya)
}

\begin{abstract}
Many organizations are facing the challenge of retaining productive employees to their competitors due to various reasons. Leadership style and career growth are becoming a major consideration for employees' desire to stay or leave the organization. To minimize turnover, institutions of higher learning are concerned with identifying the major reasons behind it. The study seeks to analyze the leadership styles and career growth in public universities as a determinant of employee turnover. The study adopted a descriptive research design. Organizations embracing appropriate leadership styles are less likely to have employee turnover. Most employees would prefer organizations that involve them in decision making and have proper channels to air their views and grievances. The results revealed that leadership styles had a significant effect on employee turnover in public universities while career development had insignificant effect on employee turnover in these universities. Data was analyzed using statistical package for social sciences (SPSS) software to generate descriptive and inferential statistics. Multiple regression analysis was used to determine the statistical relationship between the independent and dependent variables. The study recommended that universities should put in place mechanisms and policies of addressing human resource issues relating to leadership and growth of opportunities inorder to reduce turnover.
\end{abstract}

Key words: turnover, employees, universities, leadership styles, human resource, career growth

\section{Background}

\section{CHAPTER ONE INTRODUCTION}

Organizations are facing a major challenge dealing with the increasing rate of employee turnover.

Satisfactory leadership styles are the base and fundamental in the running of any organization. A leader who has the ability to give direction and guidance to employees wins the heart of employees and leads them towards achieving the organizational goals. Turnover of employees is one of the most testing issues of the present industry in light of the fact that employees are the spirit of an organization. Where there is high turnover, there is exists disparity and wastage both in management and personnel. When a business has a high turnover compared to its rivals, it implies that employees of that organization have a shorter tenure than those of different organizations in a similar industry (Phillip \& David 2012). 
A high loss of human resources in an organization is harmful to its productivity especially where skilled and experienced employees who are leaving the labour population contain a high level of new employees. In any case when turnover occurs, it affects the organization in various ways and at times lead to great loss and wastage of resources (Armstrong, 2009). In other cases, organizations have learnt that turnover is considerable reduced by addressing issues affecting employees are addressed instantly and professionally.

\section{General objective}

The general objective of the study was to examine the effects of leadership styles and career growth on employee turnover in public universities.

\section{Problem Statement}

Voluntary turnover represents an exodus of human capital from an organization. This calls for subsequent replacement process which incurs costs to the organizations. Employee turnover is expensive in any organization and is considered a challenge facing organizations today. When employees leave, the replacement process which includes selecting, recruitment and induction increases the costs of the institution. Output is affected especially in cases where the organization involves overtime to complete the work left by employee. The loss of intellectual capital increases cost and lowers the organization's reputation. If turnover is not well managed it affects organizations in terms of personal costs which affect profitability. Public Universities are experiencing increasing rate of turnover due to competition. This is as a result of various Human resource factors that employees feel they are not met. The university management is still looking for solutions to increasing rate of turnover in public universities.

\section{CHAPTER TWO LITERATURE REVIEW}

\section{Introduction}

This chapter explores the literature from books, journals, internet and magazine. Theoretical and empirical review of literature and conceptual framework is presented to help understand the subject under investigation. The literature considers the information on what other scholars have found in the areas of employee turnover. This study has borrowed from various authors dating back in 1991. These works have contributed greatly particularly in the area under study and they have not been revised meaning they are classic books.

\section{Employee Turnover}

With the public universities numbering 31, there is increased rate of turnover between the universities in search of greener pastures (Commission of University Education (CUE), 2015). The study pointed out other factors that may affect staff turnover such as amount of salary earned compared to other private and public institutions, incentives offered for working unusual hours, other benefits offered, equitable distribution of work effective communication within the organization, promotions based on career development, reasonable number of working hours per day, ability to achieve the desired balance between work and family life, management recognition of professional growth and career development. The finding of this study reaffirm earlier study by Kazi (2011), who pointed out that employee turnover can be as a result of components outside administration's control like demise of a worker, dissatisfaction of fundamental needs of life and wellbeing issues and different variables by a worker in accomplishing individual satisfaction in employment in fulfillment of pay, nature of work, supervision, authority, distributive and procedural equity. 


\section{Leadership Style and Employee Turnover}

Leadership is the capacity to influence others freely to behave in an unexpected way (Armstrong 2012). It involves influencing people in order to get them perform at their best and achieve the desired results.

In organizations where management adopts authoritative leadership style and dictate to employees how things should be done there is likelihood of poor communication hence turnover. The most essential duty of a leader is to make the institution attractive with a strategic outlook and turnaround skills and experience (Daily Nation, 2013). The leadership and supervisory role is important in employee retention as employees leave their employers and not the organization (Beardwell, 2007). Leaders, who demonstrate interest and concern for employees, face low turnover. Authoritative leadership regularly leads to increased levels of absenteeism and turnover as employees are usually not satisfied and motivated.

The Public Universities Inspection Board (GoK, 2006), emphasizes that good administration norms in public universities in Kenya is necessary since it improves quality and significance, prompting cost effective use of assets and empowering advancements among staff and students to work towards perfection. The present situation of limited resources, extensive lawbased space and emphasis on good administration require that there be a change in the outlook in public universities towards leadership styles which are straightforward, responsible, result oriented, innovative, cost effective and inclusive.

One of the most important roles of management is to make the work environment attractive to employees. It also involves influencing these workers' choice to be loyal and stay in the organization even when other openings for work exist outside the organization (Michael, 2008). Consultation with and participation by employees in decision- making make them feel part of the organization and give them a possession in the outcomes of these decisions (Tettey, 2006). An incompetent leader may lead the employees' poor performance, stress, low job commitment and dissatisfaction hence turnover (Gwavuya, 2011). Research conducted on the state of South African training industry indicated leadership style as the most determinant of turnover in South Africa (Netswera, 2005).

\section{Career Growth and Employee Turnover}

Career growth is the possibility that a worker gets an advancement and profession improvement experiences from increased duties and contender assignments (Weer, 2006). A favourable career growth policy requires the employee to reimburse the organization by retaining their present occupations without changing their employments every now and again.

Career growth enables institutions to be consistent with their mandate as centers of concepts and advancement (Tettey, 2006). According to Dockel (2003), investing in training is an approach to indicate the importance of employees to the organization. Employees should not only be remunerated monetarily buts as well be offered chances to develop their career within the organization and advancement offers opportunities for progression (Dockel, 2003). As indicated by Armstrong (2010), the purpose of the promotion procedures of an organization should empower administration to acquire the best talents available in the organization to fill more senior posts and second to give workers the chance to advance their professions inside the organization, as per the opportunities available considering the equal opportunity strategies and their own capabilities. 


\section{Expectancy Theory}

This theory was developed by Vroom in the early 1960s is one of the widely used theories in understanding employee turnover intentions and retention (Tettey, 2006). Expectancy theory argues that people join organizations with expectations and values, and if the organizations meet their expectations, employees will remain loyal members of these organizations.

Structural expectations like shared communication, equitable rewards, work autonomy, job security, and inclusion in decision making for academic and administrative staff enhance job satisfaction and their absence leads to employee turnover (Daly, 2006). Employees will report higher levels of job satisfaction and commitment to the employer if these structural expectations are met hence strengthened need to stay in the organization (Price, 2001). On the contrary, when structural expectations are not met, the levels of satisfaction and commitment decline, and need for an employee to leave increases. Rewards may not be directly attached to effort and performance; in some organizations rewards like raises depend on a contract or other factors like education or specific job skills. This study derived one variable from the expectancy theory career growth.

\section{Influence of leadership styles on employee turnover}

Leadership style involves influencing people in order to get them perform at their best and achieve the desired results. Poor leadership style strains the relationship between employees and employer. This happens in cases where leaders adopt the authoritative management style. Leaders should make the institution attractive with a strategic outlook and turnaround skills and experience (Daily Nation, 2013).

Abassi \& Holman (2000), in the study of employee voluntarily leaving the organization the US public and private sectors, found out that there determinants that contribute to employee turnover are approaches like managerial approach.

The Public Universities Inspection Board (GoK, 2006), emphasizes that good administration norms in public universities in Kenya is necessary since it improves quality and significance, prompting cost effective use of assets and empowering advancements among staff and students to work towards perfection. One of the most important roles of management is to make the work environment attractive to employees. It also involves influencing these workers' choice to be loyal and stay in the organization even when other openings for work exist outside the organization (Michael, 2008). Consultation with and participation by employees in decision- making make them feel part of the organization and give them a possession in the outcomes of these decisions (Tettey, 2006).

\section{Influence of Career Growth on Employee Turnover}

According to Weer (2006), career growth is the possibility that a worker gets an advancement and profession improvement experiences from increased duties and contender assignments. A favourable career growth policy requires the employee to pay back the organization by retaining their present occupations without changing their employments every now and then.

Through career growth, institutions are enabled to be consistent with their mandate as centres of concepts and advancement (Tettey, 2006). In insecure organizations, workers tend to leave and search for places that are steady since with stable organizations they can foresee their professional success. When properly structured and applied, training and development provide competitive advantage to organizations. According to Dockel (2003), investing in training is an approach to indicate the importance of employees to the organization. 


\section{Operational Framework}

An operational framework establishes if there is a relationship between the parameters stated and the dependent variable; in this case the employee turnover. It shows the parameters that will be used to test each variable.

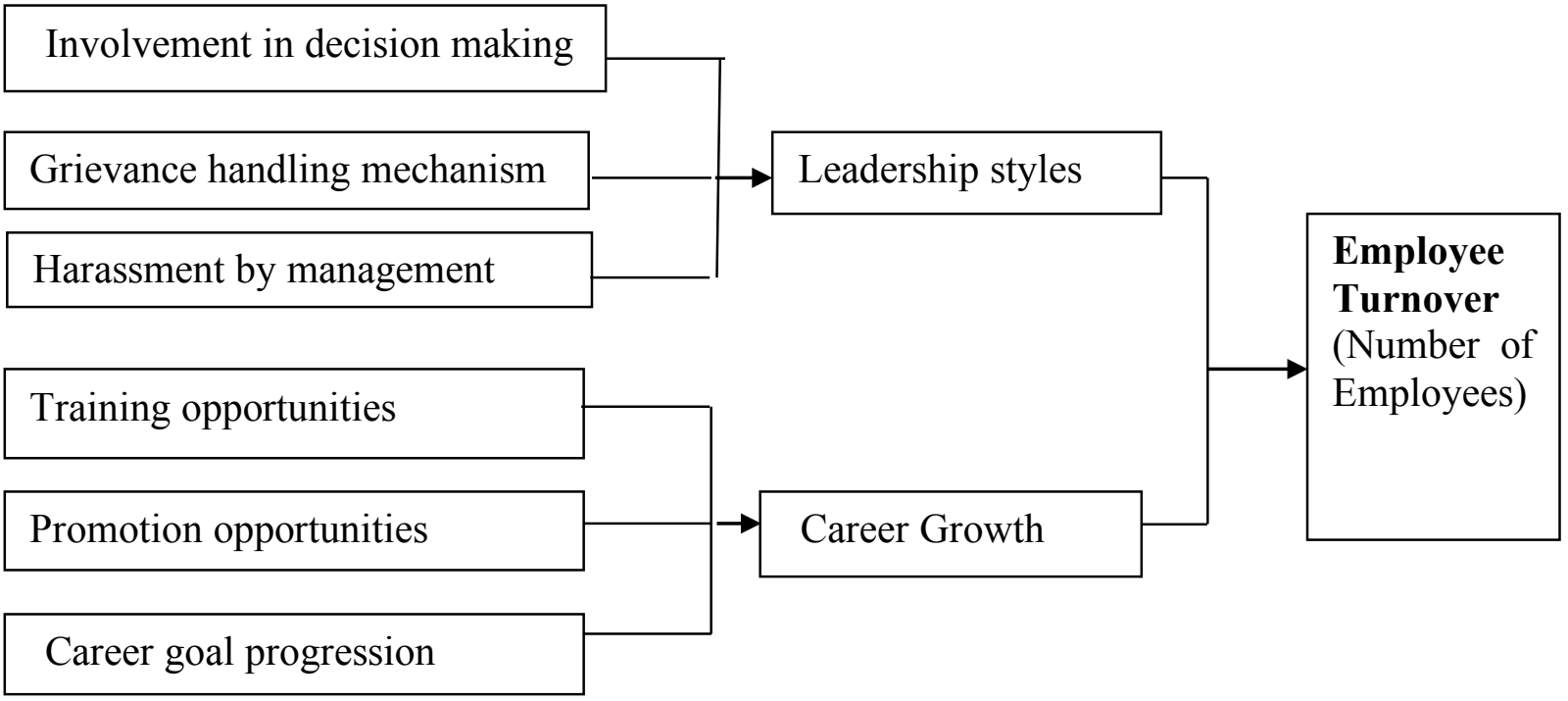

Parameters

Independent Variables

Dependent Variable

Fig 1.1 Operational Framework

\section{CHAPTER THREE RESEARCH METHODOLOGY}

\section{Introduction}

This section gave a structure for conducting the research. It gave information on the approach that was used as a part of the research design, sample size, target population, sampling technique and methods of data collection, data analysis and interpretation.

\section{Research Design}

This study used a descriptive research design, which determines and reports the way things are (Mugenda \& Mugenda, 2003). In this study, both qualitative and quantitative data was collected. The latter involves quality while the former involves determining the amounts applied to a phenomenon (Kothari, 2010). The objective of the study was achieved by administering questionnaires which gave a more accurate response from the respondents and also saved time. Descriptive research design is more accurate and less time consuming and less costly.

\section{Target population}

Target population is defined by Mugenda and Mugenda (2003), as what researcher wants to generalize the results of the study. It provides a solid foundation and first step upon which to build the validity and reliability of the study.

In this study, target population comprised of people with some common characteristics from which the researcher made the generalization of the study. 
Table 3.3.1 Target population

\begin{tabular}{lll}
\hline Department & Population & Percentage (\%) \\
\hline DeKUT & 480 & 51 \\
Karatina University & 423 & 49 \\
Total & $\mathbf{9 0 3}$ & $\mathbf{1 0 0}$ \\
\hline
\end{tabular}

Source: HR (July, 2016)

\section{Sampling design and Sample Size}

The study adopted a stratified random sampling to draw the sample which is a procedure that requires the population to be divided into small groups called strata (Charles \& Fen, 2007). This technique of sampling guarantees that particular groups are represented, proportionally in the sample by choosing people from strata list. Stratified sampling gives reliable and detailed information (Kothari, 2004).

As indicated by Mugenda \& Mugenda (2003), a sample size of between $10 \%$ and $30 \%$ is a good representation of the population. In this study, the researcher used the lower limit of the sample which was $10 \%$ of the total population. This implied that 90 respondents were chosen randomly from the academic and administrative staff in the two universities.

\section{Data Collection Method}

The study used primary data, open-ended and close-ended questionnaires were used to collect information from respondents. Questionnaires are easy to administer, less costly and ensure there is reliable response (Mugenda \& Mugenda, 2003). Questionnaires were dropped and picked after one week.

\section{Reliability and Validity of Instruments}

Reliability is the consistency of measurement. It is frequently tested using the test and retest method (Walliman, 2001). The researcher used test re-test method to test the re liability. Validity is the meaningfulness of the research components (Drost, 2011). In this research, validity was achieved by use of open-ended questions which helped get the in depth analysis of the respondents' answers.

\section{Data analysis and presentation}

Analysis of data is the process of bringing order, structure and interpretation to the mass of collected data (Marshal \& Rossman 2010). The collected data, with the aid of questionnaire was processed using the Statistical Package for Social Science (SPSS) version 20.0 by first coding the responses In addition, multiple regression analysis was used to test inferential statistics in order to establish relationship between the independent and the dependent variables.

\section{Introduction}

\section{CHAPTER FOUR FINDINGS AND DISCUSSION}

The broad objective of the study was to assess the determinants of employee turnover in two public universities in Nyeri County. Structured questionnaires were used to collect data from the respondents of Dedan Kimathi University of Technology and Karatina University main campuses employees. Data was coded, analyzed and the results obtained using descriptive and inferential statistics guided by the research objectives and research questions. The findings were presented in form of frequency tables and their implications explained. Multiple 
regression analysis was used to determine the relationship between the dependent and independent variables.

\section{Response Rate}

Data that was analyzed was obtained from seventy eight (78) respondents out of the targeted ninety (90) employees of Dedan Kimathi University of Technology and Karatina University. Out of the 78 respondents 35 were from DeKUT and 43 from KarU. Thus, the response rate was achieved at $86.7 \%$, this response rate was considered to be adequate since the respondents' confidentiality was maintained hence more responses (Mangione, 1995).

\section{Gender of Respondents}

The researcher sought to establish the gender of the respondents in the study. The findings indicated that $61.5 \%$ of the respondents were male while $38.5 \%$ were female. This was an indication that there was no significance gap between the numbers of male and female employees in public universities in Nyeri County. This could be attributed to the nature of work that cut across either gender as long as they possess appropriate qualification.

\section{Age of the Respondents}

The researcher sought to establish the age of the respondents. The study revealed that $11.5 \%$ of the respondents were between 20-30 years, 37.2\% were aged between 31-40 years, and $41.0 \%$ were aged between $41-50$ while $10.3 \%$ were above 50 years. This was an indication that majority of the respondents were aged between 31-50 years. This was attributed to the fact that major recruitment drive had been conducted in the two universities for the last six years since they became fully fledged universities. This implied that young workforce may be utilized for longer period if satisfied with the work environment, opportunities for career growth, remuneration and management style.

\section{Period worked with former employer}

The researcher sought to establish the period staff recruited to work in the university has worked with the former employers. $14.2 \%$ of the respondent have worked with former employer for less than one year, $34.6 \%$ for a period between $2-5$ years, $28.2 \%$ 5-10 years while $23.1 \%$ for a period more than 10 years. Thus this study indicated that employee can leave employment any period regardless of the number of years they have been working with the organization as long as better opportunities are availed.

\section{Leadership Style and employee turnover}

Objective one of the study sought to investigate influence of leadership styles on employee turnover in public universities in Nyeri County. Regression analysis was conducted to determine the influence of leadership styles factors on employees' turnover in public universities. From the regression results the $\mathrm{R}$ value was 0.684 indicating that there was a positive relationship between leadership styles on employees' turnover in public universities. The R squared (R2) value of 0.468 shows that 46.8 percent of employee turnover in public universities was explained by leadership styles. The remaining 53.2 percent was explained by other factors.

\section{Leadership Style and employee turnover Coefficients}

The coefficient table indicated that grievance handling mechanism had positive and significant effect on employee turnover with $\beta=0.637$ at $p$ value 0.000 . This meant that if there were clear guidelines on how grievances are handled in public universities, employees would tend to leave the organization when aggrieved by their supervisors. Involvement in decision-making and harassment by management had insignificant effect on employee turnover with $\beta=0.178$ 
at $p$ value of 0.352 and $\beta=0.031$ at $p$ value of 0.760 respectively. The finding of this study was that grievance handling mechanism had positive and significant effect asserts study by Sujeewa (2011) where grievance handling that was found to be unfair and injustice was a main determinant of employee turnover. According to Abassi \& Hollman (2000), the determinants that contribute to employee turnover are approaches like managerial approach to critical issues affecting employees.

\section{Perception on Leadership Style and employees' turnover intentions}

The researcher sought to establish the perception of the respondents on whether leadership style determines employees' turnover. From the results, majority of the respondents, $75.6 \%$ said that leadership style influence employees' turnover to a very great extent. The finding that majority of the employees felt that leadership style affected employees' turnover to a very great extent is consistent with earlier findings by Beardwell (2007), who pointed out that autocratic leadership often led to high levels of absenteeism and staff turnover intent as employees become angry and demotivated.

\section{Career Growth and Employee Turnover}

Objective four of the study sought to evaluate how career growth affected employee turnover in public universities in Nyeri County. Regression analysis was done to determine the effect of each factor of career growth on employee turnover in public universities. The discussion was linked to the research objectives and research questions to establish the effect of career growth on employees' turnover in public universities.

\section{Career Growth and employee turnover Model Summary}

From the regression results, the $\mathrm{R}$ value was 0.744 indicating that there was a positive relationship between career growth and employee turnover in public universities. The $\mathrm{R}$ squared (R2) value of 0.554 shows that 53.6 percent of employee turnover in public universities is explained by career growth. The remaining 46.4 percent is explained by other factors. The model was significant with the $F$ ratio $=30.624$ at $p$ value $0.000<0.05$. This was an indication that career growth had a positive and significant effect on employee turnover in public universities.

\section{Career Growth and employee turnover ANOVA Summary}

The coefficient table indicates that promotion opportunities and possibility of career goal progression had positive and significant effect on employee turnover with $\beta=0.466$ at $p$ value 0.000 and $\beta=0.357$ at $p$ value 0.000 respectively. This meant that if universities had promotion opportunities and possibility of career goal progression staffs would reconsider their decision to leave the university. Provision of training opportunities had insignificant effect on employee turnover with $\beta=0.092$ at $p$ value 0.588 which was an indication that training opportunities may not be a main consideration whether to leave an organization or not.

From the results, half of the respondents said that career growth affected employees' turnover to a very great extent. The finding that majority of the employees felt that career growth affected employees' turnover to a very great extent is consistent with earlier findings by Dockel (2003), who argued that employees should be rewarded financially as well as be offered opportunities to grow within the organization.

\section{Perception on career growth and employees' turnover intentions}

The researcher sought to establish the perception of the respondents on whether career growth influenced employees' turnover intentions. From the results, half of the respondents 
said that career growth affected employees' turnover to a very great extent. The finding that majority of the employees felt that career growth affected employees' turnover to a very great extent is consistent with earlier findings by Dockel (2003), who argued that employees should be rewarded financially as well as be offered opportunities to grow within the organization.

\section{Rate Employee Turnover in Your Institution}

The study sought to establish the rate of the employees' turnover in public universities. The respondents were required to indicate the rate of turnover in a scale of 1 to 5 ranging from very high to very low.

The finding of the study revealed that $5.13 \%$ of the respondents rated employee turnover very high 5.13\%, 12.82\% rated staff turnover high, 33.33\% moderate, $42.31 \%$ low while $6.41 \%$ rated the staff turnover very low. The study indicated that employees turnover in public universities was either moderate or low although a high proportion rated the turnover as high.

\section{CHAPTER FIVE FINDINGS, CONCLUSION AND RECOMMENDATIONS}

\section{Introduction}

This chapter is a synthesis of the entire report and contains the summary of the findings, conclusion arrived at and policy recommendations arising from the study. Research gaps which were identified during the study are also identified as basis for future studies.

\section{Findings}

\section{Leadership Style and Employee Turnover}

Objective two of the study sought to investigate impacts of leadership styles on employee turnover in public universities in Nyeri County. In order to ascertain the relationship between leadership styles on employee turnover in public universities, the researcher carried out a multiple regression analyses. The regression results indicated a positive and significant relationship between leadership styles factors and employee turnover in public universities with $r=0.684$ and the $R$ squared value of 0.468 . At $5 \%$ level of significance the $p$-value was 0.000. The findings of the study further indicated that grievance handling mechanism had positive and significant effect on employee turnover in public universities. Involvement in decision-making and harassment by management had positive but insignificant effect on employee turnover in public universities. The study further revealed that when all the independent variables were regressed together, leadership styles had a positive and significant effect on employee turnover in public universities with $\beta=0.363$ at $p$ value 0.000 .

\section{Career Growth and Employee Turnover}

Objective four of the study sought to evaluate how career growth affects employee turnover in public universities in Nyeri County. In order to ascertain the relationship between career growth on employee turnover in public universities, the researcher carried out a multiple regression analyses. The regression results indicated a positive and significant relationship between career growth factors and employee turnover in public universities with $\mathrm{r}=0.744$ and the $r$ squared value of 0.554 . At $5 \%$ level of significance the $p$-value was 0.000 . The findings of the study further indicated that promotion opportunities and possibility of career goal progression had positive and significant effect on employee turnover in public universities. Provision of training opportunities had positive but insignificant effect with $r=0.324$ on employee turnover in public universities. The study further revealed that when all the independent variables were regressed together, career growth had a positive and significant effect on employee turnover in public universities with $\beta=0.115$ at $p$ value 0.488 . 


\section{Conclusions}

The study revealed that majority of the employees working in public universities previous worked with private institutions where they left voluntarily. Half of those employees had worked for less than five years before joining public universities. In addition poor remuneration, poor incentives, lack of fridge benefits, unclear grievances handling mechanism, lack of job security and safe working environment, failure of promotion opportunities and career goal progression were some of the factors that influenced them to leave the former employer. This is an indication that universities should address these factors in order to retain experienced and committed staff.

\section{Leadership Style and Employee Turnover}

Leadership Style was a factor that affects employees' turnover, this may be attributed to the interest and concern management show for the employees, where management has put in place clear grievance handling mechanism employees turnover tend to be low. In addition managerial approaches adopted by leaders may influence their decision to leave or stay in the organization.

\section{Career Growth and Employee Turnover}

The study established that career growth had insignificant effect on employee turnover. This is an indication university employees do not value provision of training opportunities and promotion opportunities if their salaries are not reviewed upward. This means that even if universities offer opportunities for training by supporting employees to reach their career goals and do not review their salaries the possibilities of leaving the universities to join other institutions with higher pay is very high. This contradicts other researchers who argued that employee training shows the management's commitment to a long-life relationship with employees thus increasing retention and reducing turnover decisions.

\section{Recommendations}

The finding revealed that leadership style had significant relationship on staff turnover; therefore universities should put in place policies and mechanisms of addressing human resources issues in order to reduce staff turnover.

Career growth had insignificant relationship on employee's turnover. The recommendations are that university management should not consider provision of training opportunities as a strategy to retain employees. This means that even if universities offer opportunities for training by supporting employees to reach their career goals and do not review their salaries the possibilities of leaving the universities to join other institutions with higher pay is very high.

\section{Areas of Further Studies}

The present study was carried in public universities in Nyeri County. It is suggested that a study focusing on determinants of employees' turnover in private universities should be put into consideration. This study considered four variables, namely remuneration, leadership styles, working condition and career growth. Future researchers should also focus on other types of composition variables that employee turnover. Finally, future researcher should find out the challenges universities face when addressing employees' turnover.

\section{References}

Abbasi, S.M. \& Hollman, K.W. (2000). Turnover: The real bottom line . Public personnel Management, 2 (3), 333342 .

Armstrong, M. (2009). Handbook of Human Resource Management practice, (11 th ed.). London: Kogan Page. 
Armstrong, M. (2012). Essential Human Resource Management Practice: A Guide to People Management. (12th ed.). London: Kogan Page.

Beardwell, J., \& Claydon, T. (2007). Human Resource Management: A Contemporary Approach, Prentice Hall, England, UK.

Commission of University Education ;(2015).Accreditation Status: Retrieved from: www.CUE.or.ke/services/accreditation/status-of-universities.

Daly, C.J. (2006). Greener Pastures: Faculty Turnover Intent in Urban Public Universities. Journal of Higher Education, 77.5 (8/9), 59-64.

Dockel, A. (2003). The Effect of Retention. Factors on Organizational Commitment: University of Pretoria, S.A. International Journal of Management, 2 (3): 15-22.

Drost, E. (2011). Validity and Reliability in Social Science Research, Education Research and Perspectives, 105123.

Government of Kenya (GoK), (2006). Transformation of Higher Education and Training in Kenya: Report of the Public Universities Inspection Board. Nairobi.

Gwavuya, F. (2011). Leadership Influences on Turnover Intentions of Academic Staff in Institutions in Zimbabwe. Academic Leadership Journal, 9 (1), 1-15.

Kazi G.F. \& Zedah Z.F (2011).The contribution of individual variables: job satisfaction and job turnover. Interdisciplinary Journal of Contemporary Research in Business, 3 (5), 984-991.

Kothari, C.R. (2014). Research Methodology: Methods and Techniques, (3rd Ed.). New Delhi: New Age International Publishers.

Mangione, T.W., (1995). Mail Surveys: Improving the Quality; Applied Social Research Methods; (1st ed.). Sage Publications, USA.

Marshall C., \& Rossman G., (2010). Designing Qualitative Research: (5th ed.). Sage publications, California, USA.

Michael, S.O., (2008). Motivational Strategy for Employee Retention and Turnover in Public and Private Sector Organizations. Cape Town, South Africa.

Mugenda, O.M. \& Mugenda, A.G. (2003). Research Method. Quantitative and Qualitative, Approaches. Nairobi (Kenya Acts) Press, African Centre for Technology Studies.

Netswera, F.G., (2005). Employee Retention Factors for South African Higher Education Institutions: S.A Journal of Human Resource Management, 3 (2), 36-40.

Phillip C.B. \& David G.A. (2012). Managing Employee Turnover: Myths to Dispel and strategies for effective Management. (1st ed).

Price, J. (2001). Reflections on Determinants of Voluntary Turnover. International Journal of Manpower 22, 600624.

Tettey, J.W. (2006). Staff Retention in African Universities: Elements of a Sustainable Strategy, USA,Washington, DC:

Walliman N., (2010).Research Methods: The Basics, Taylor \& Francis Ltd, London UK. 